\title{
Numerical Modeling and Mechanical Analysis of Flexible Risers
}

\author{
J. Y. Li, Z. X. Qiu, and J. S. Ju \\ College of Water Resources and Civil Engineering, China Agricultural University, Beijing 100083, China \\ Correspondence should be addressed to J. S. Ju; jasonnuig@gmail.com
}

Received 19 September 2014; Accepted 15 December 2014

Academic Editor: Chenfeng Li

Copyright (C) $2015 \mathrm{~J}$. Y. Li et al. This is an open access article distributed under the Creative Commons Attribution License, which permits unrestricted use, distribution, and reproduction in any medium, provided the original work is properly cited.

\begin{abstract}
ABAQUS is used to create a detailed finite element model for a 10-layer unbonded flexible riser to simulate the riser's mechanical behavior under three load conditions: tension force and internal and external pressure. It presents a technique to create detailed finite element model and to analyze flexible risers. In FEM model, all layers are modeled separately with contact interfaces; interaction between steel trips in certain layers has been considered as well. FEM model considering contact interaction, geometric nonlinearity, and friction has been employed to accurately simulate the structural behavior of riser. The model includes the main features of the riser geometry with very little simplifying assumptions. The model was solved using a fully explicit time-integration scheme implemented in a parallel environment on an eight-processor cluster and $24 \mathrm{G}$ memory computer. There is a very good agreement obtained from numerical and analytical comparisons, which validates the use of numerical model here. The results from the numerical simulation show that the numerical model takes into account various details of the riser. It has been shown that the detailed finite element model can be used to predict riser's mechanics behavior under various load cases and bound conditions.
\end{abstract}

\section{Introduction}

The unbonded flexible riser is a pipe composed of several layers without adhesive agents between the layers. It is widely used in the deep sea oil industry for its capacity dealing with large deformation and displacement due to its lower bending stiffness comparing with rigid steel risers. Different layers are designed for specific functions. Achieving the advantage of flexible risers requires complicated inner structure. One of the correlative disadvantages is the difficulty of understanding the mechanical behavior of the riser particularly under the very deep water.

Current methods are generally divided into two categories: analytical methods and numerical methods. In the past decades, researchers have conducted several analytical works on this subject. Among the first pioneers, Knapp [1] derived the stiffness matrix for a helically armored cable subjected to tension and torsion. He took into account the compressibility of the core and the variation in lay angles. The research on the response of helically armored cables subjected to tension, torsion, and bending was conducted by Lanteigne [2]. In his study, the influences of internal radial forces and curvature on the effective flexural rigidity were investigated. Feret and Bournazel [3] presented a formulation for the slip of tendons undergoing bending on assumption that armor tendons followed a geodesic path once slip took place. Kraincanic and Kebadze [4,5] presented a nonlinear formulation in consideration of the variation of the bending stiffness due to frictional sliding between layers, and an analytical model of an unbonded flexible pipe was proposed.

However, all the analytical models share many simplified assumptions inevitably [6-8], which significantly limit the application range of the results. On the other hand, the analytical models are quite complicated due to the large nonlinearity of the complex structure [9]. What is mentioned above motivates many researchers to study the refined finite element models, which takes into account many details of the real risers that the analytical model can hardly contain. And the detailed finite element model can be achieved conveniently benefiting from the wide use of computers. Bahtui et al. developed a finite element model for unbonded flexible riser with only two structural layers [10]. However, papers in this field are still quite rare.

In this paper, a further research on the refined finite element model of 10-layer unbonded flexible riser is conducted. All layers are modeled separately. FEM model considers 


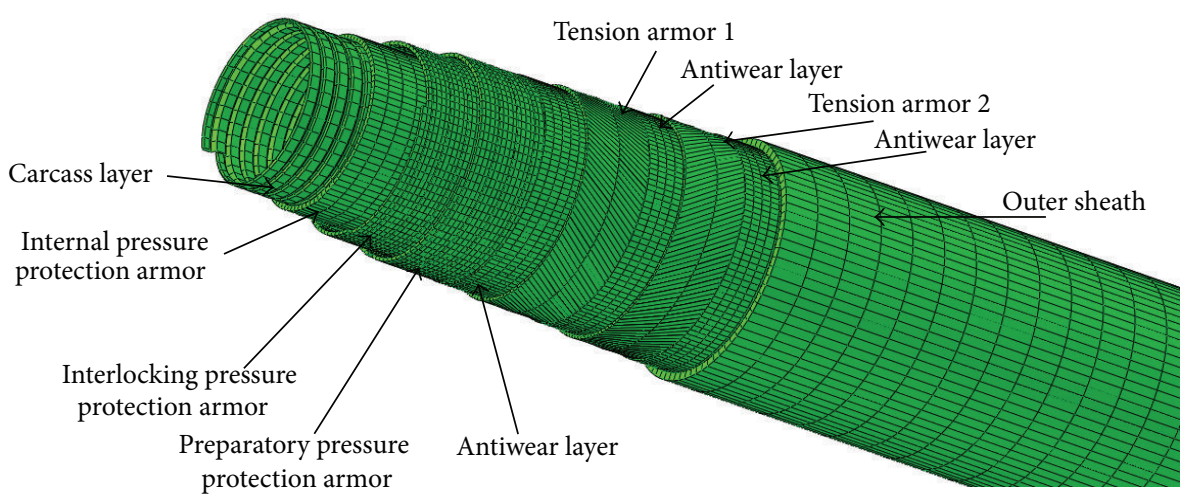

Figure 1: Ten layers' riser.

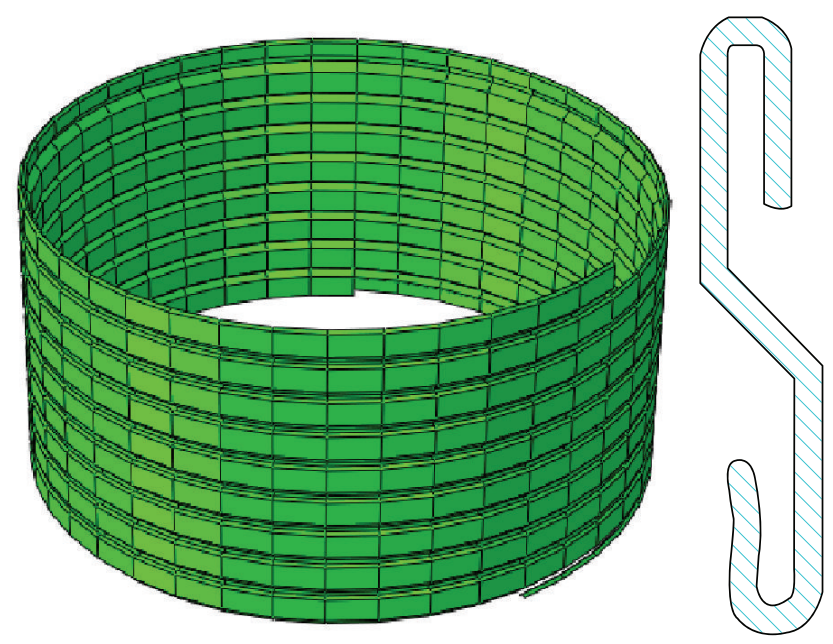

FIGURE 2: Section and model of carcass layer.

contact interaction, geometric nonlinearity, and friction. The model includes the main features of the riser geometry with very little simplification. And the mechanical behaviors of the riser under three load conditions are obtained.

\section{Finite Element Model}

A detailed finite element model developed using ABAQUS by parametric method is shown in Figure 1 [11]. Ten layers are simulated separately considering the contact interfaces. The coefficient of friction between layers is assumed 0.1 . Hourglass control is considered in this study.

The sequence of layers is listed in Table 1.

The finite element model was created in a global cylindrical coordinate system with its origin located at the center of the riser's bottom. The model consisted of ten separate cylindrical layers.

Carcass layer was modeled by 3D 4-node reducedintegration shell element. There were 55440 elements and 61610 nodes adopted. Its section and interlocking structure show in Figure 2.
TABLE 1: Layers of the riser.

\begin{tabular}{ll}
\hline Layer & Type \\
\hline 1 & Carcass layer \\
2 & Internal pressure protection armor \\
3 & Interlocking pressure protection armor \\
4 & Preparatory pressure protection armor \\
5 & Antiwear layer \\
6 & Tension armor 1 \\
7 & Antiwear layer \\
8 & Tension armor 2 \\
9 & Antiwear layer \\
10 & Outer sheath \\
\hline
\end{tabular}

As shown in Figure 3, internal pressure protection armor layer was modeled by 3D 8-node linear brick, reducedintegration element. There are 25200 elements and 38052 nodes for this layer.

Interlocking pressure protection armor and preparatory pressure protection armor layers were composed of channel 


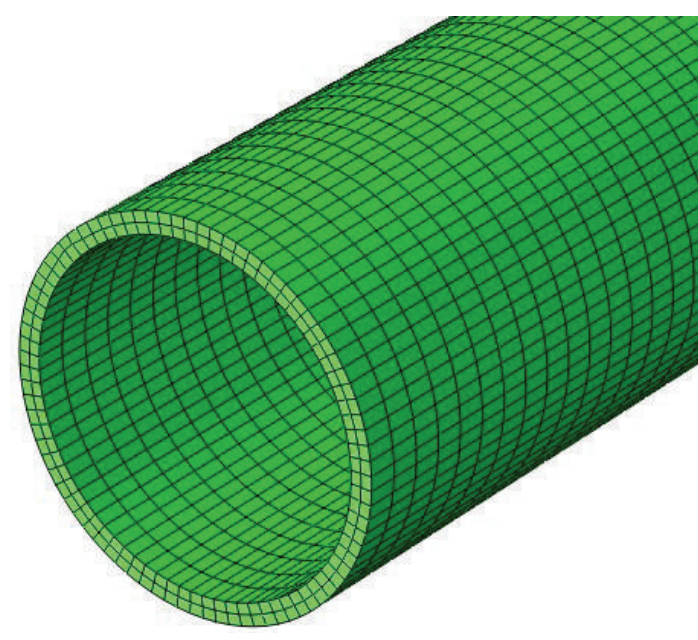

FIGURE 3: Model of internal pressure protection armor layer.

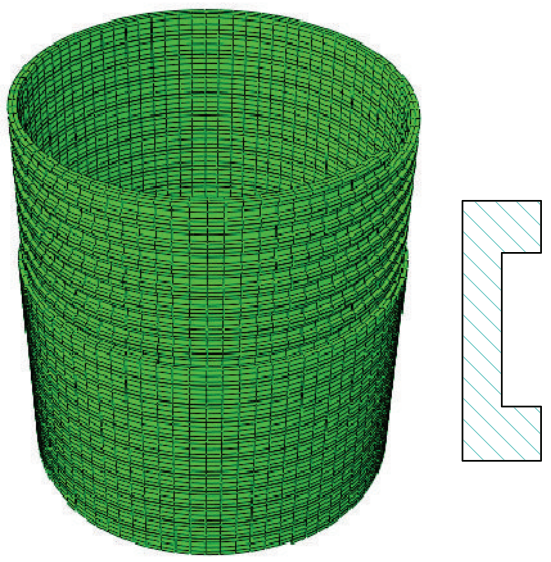

FIGURE 4: Section and model of the pressure protection armor layers.

steel strips; they made up the pressure protection armor together (as shown in Figure 4). Both of the layers were modeled by 3D 8-node linear brick, reduced-integration element. 113280 elements and 264348 nodes were used here.

There are three antiwear layers modeled between preparatory pressure protection armor, tension armor 1, tension armor 2, and outer sheath. The model of antiwear layer is shown in Figure 5. 3D 8-node linear brick, reduced-integration element was selected for the modeling. There are 89000 elements and 178712 nodes in total.

As shown in Figure 6, two tension armor layers are spirally woundF in opposite directions. Tension armor 1 consisted of 58 steel strips while tension armor 2 consisted of 60 . Both of them were modeled by 3D 8-node linear brick, reduced-integration element. There are 7772 elements and 23664 nodes for tension armor 1 and 8040 elements and 24480 nodes for tension armor 2 .

Figure 7 shows the detailed dimensions of the riser's cross section composed of 10-layer element model. Due to the complication and scale of the structure, a parametric

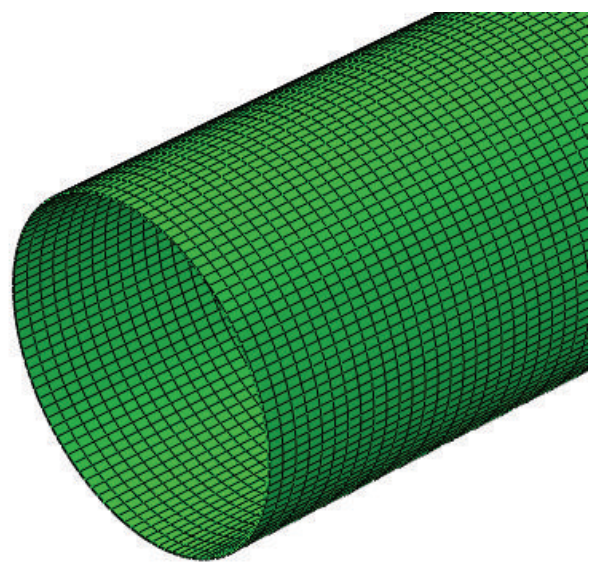

Figure 5: Model of antiwear layer.

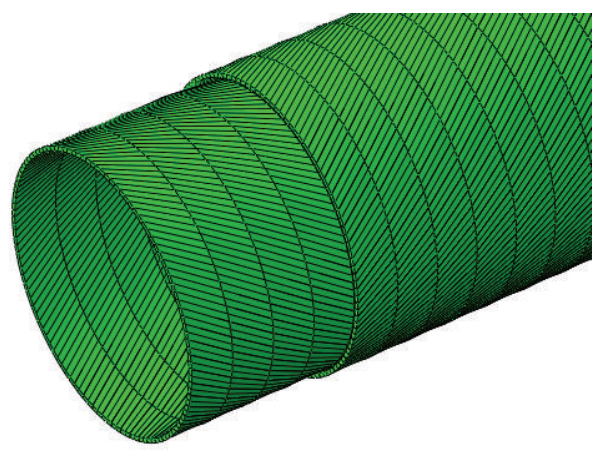

FIGURE 6: Model of tension armor layers.

modeling procedure was adopted. The model is solved in ABAQUS analysis module after modeling.

\section{Material Properties}

The material properties for layers of the flexible riser are shown in Table 2.

\section{Load Case, Calculation Results, and Analyses}

Three typical loads (tension, internal pressure, and external pressure) were applied on a $3.0 \mathrm{~m}$ long riser to demonstrate the accuracy and reliability of the method. The bottom end of the riser was constrained in all directions while the other end was totally free.

4.1. Load Case 1: Tension. In this case, a $150 \mathrm{kN}$ concentrated load was applied on the free end of the riser. Figure 8 shows the axial-deformation of the riser. The maximum stretching of the riser in axial direction is $1.935 \mathrm{~mm}$, and the elongation is about $0.0645 \%$. The maximum Mises-stress results of each layer are listed in Table 3.

As shown in Table 3, stress mostly concentrated at the tension armor layers. The maximum Mises stress for tension 
TABLE 2: Material properties.

\begin{tabular}{lcccccc}
\hline & Carcass layer & $\begin{array}{c}\text { Internal pressure } \\
\text { protection armor } \\
\text { Steel strip }\end{array}$ & $\begin{array}{c}\text { Pressure } \\
\text { protection } \\
\text { armor } \\
\text { polyethylene }\end{array}$ & $\begin{array}{c}\text { Antiwear } \\
\text { layer }\end{array}$ & $\begin{array}{c}\text { Tension } \\
\text { armor }\end{array}$ & Steel strip \\
Density $\left(\mathrm{kg} / \mathrm{m}^{3}\right)$ & 7800 & 920 & 7800 & Nylon braid & Steel strip & $\begin{array}{c}\text { Low-density } \\
\text { polyethylene }\end{array}$ \\
Young's modulus $(\mathrm{GPa})$ & 207 & 0.18 & 207 & 0.18 & 7800 & 207 \\
Poisson's ratio & 0.3 & 0.38 & 0.3 & 0.38 & 0.3 & 920 \\
\hline
\end{tabular}

TABle 3: Maximum Mises stress of each layer.

\begin{tabular}{lcccccc}
\hline & $\begin{array}{c}\text { Carcass } \\
\text { layer }\end{array}$ & $\begin{array}{c}\text { Internal } \\
\text { pressure } \\
\text { protection } \\
\text { armor }\end{array}$ & $\begin{array}{c}\text { Interlocking } \\
\text { pressure } \\
\text { protection } \\
\text { armor }\end{array}$ & $\begin{array}{c}\text { Preparatory } \\
\text { pressure } \\
\text { protection } \\
\text { armor }\end{array}$ & $\begin{array}{c}\text { Tension } \\
\text { armor 1 }\end{array}$ & $\begin{array}{c}\text { Tension } \\
\text { armor 2 }\end{array}$ \\
\hline Mises stress $(\mathrm{MPa})$ & 6.410 & 0.1104 & 14.32 & 19.61 & 98.48 & 91.51 \\
\hline
\end{tabular}

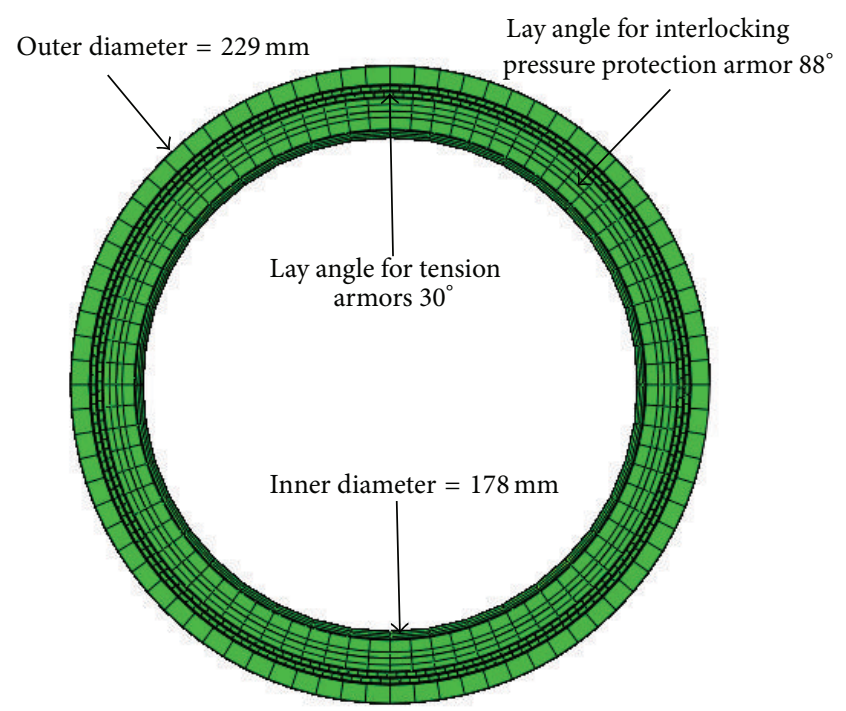

FiguRE 7: Detailed dimensions of the riser's cross section.

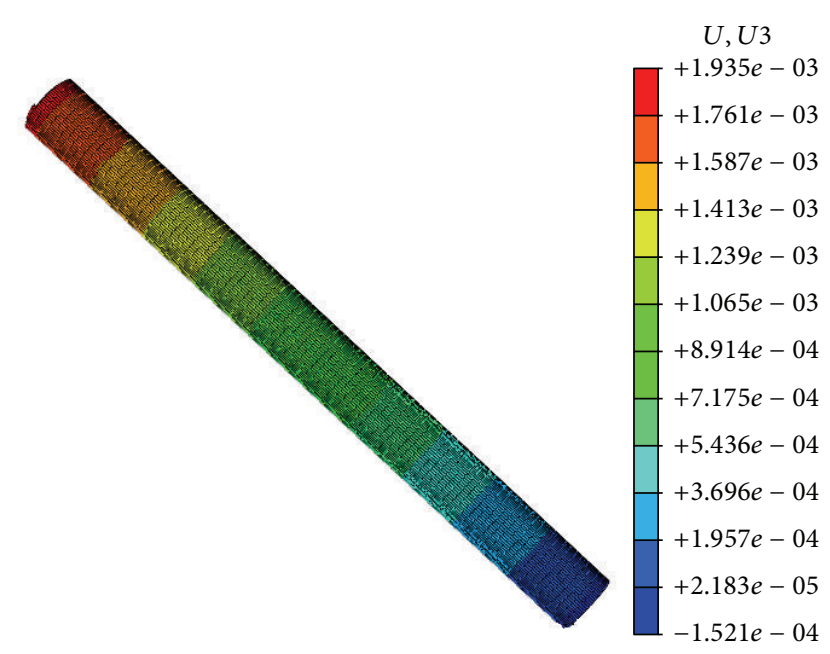

FIGURE 8: Axial-deformation of the riser under tension.

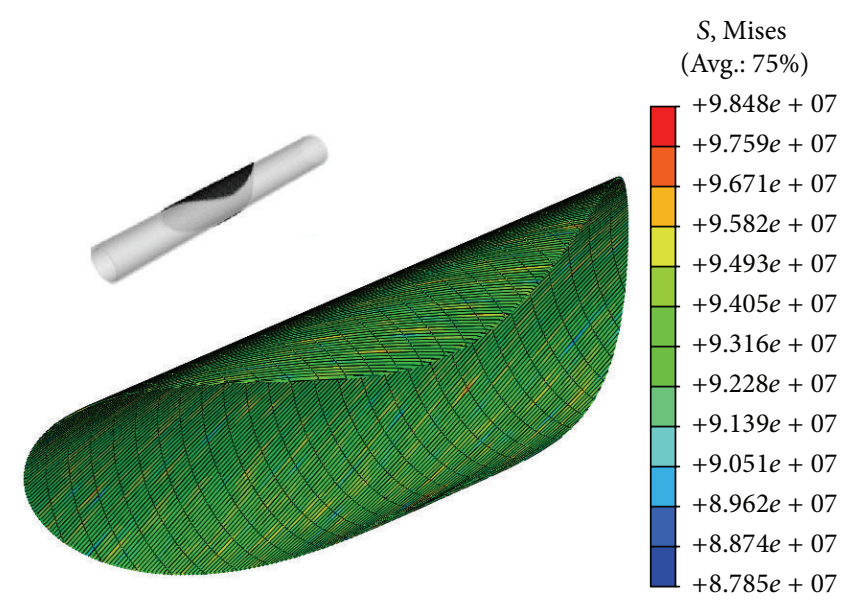

FIgURE 9: Mises-stress contour for tension armor 1 under tension.

armor 1 is $98.48 \mathrm{MPa}$. The result shows good agreement with result obtained from Recommended Practice for Flexible Pipe [12]. It can also be seen that Mises stress in tension armor 1 is slightly greater than that in tension armor 2 due to the difference in their radii. In order to achieve a better view of the maximum stress distribution, only stress results of tension armor 1 are shown in Figure 9.

The analytical result from recommended practice for tensile stress in the tension armor is given by

$$
\sigma=\frac{T}{\left(2 t_{e} \pi D \cos ^{2} \theta\right)},
$$

where $T$ is tensile load, $t_{e}$ is equivalent armor thickness, and $D$ is mean diameter of armor.

The analytical result is $87.01 \mathrm{MPa}, 8.4 \%$ smaller than the average simulation result $94.99 \mathrm{MPa}$. There is a good agreement between the analytical and numerical results. The analytical method considering the riser is more likely a continuous structure, so it cannot take full account of contact, slip, 
TABLE 4: Maximum Mises stress of each layer.

\begin{tabular}{lcccccc}
\hline & $\begin{array}{c}\text { Carcass } \\
\text { layer }\end{array}$ & $\begin{array}{c}\text { Internal } \\
\text { pressure } \\
\text { protection } \\
\text { armor }\end{array}$ & $\begin{array}{c}\text { Interlocking } \\
\text { pressure } \\
\text { protection } \\
\text { armor }\end{array}$ & $\begin{array}{c}\text { Preparatory } \\
\text { pressure } \\
\text { protection } \\
\text { armor }\end{array}$ & $\begin{array}{c}\text { Tension } \\
\text { armor 1 }\end{array}$ & $\begin{array}{c}\text { Tension } \\
\text { armor 2 }\end{array}$ \\
\hline Mises stress $(\mathrm{MPa})$ & 1.598 & 2.602 & 102.0 & 99.44 & 21.41 & 27.22 \\
sheath \\
\hline
\end{tabular}

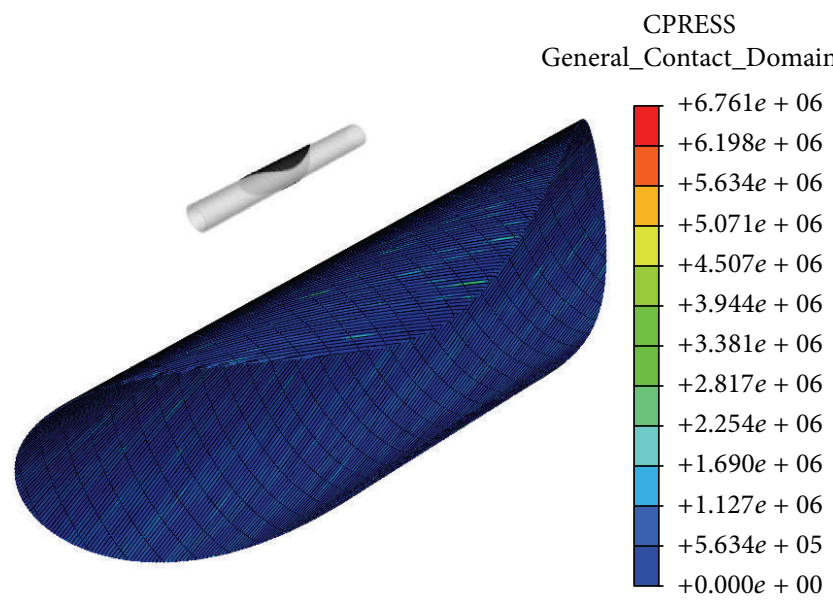

FIGURE 10: Contact pressure contour for tension armor 1 under tension.

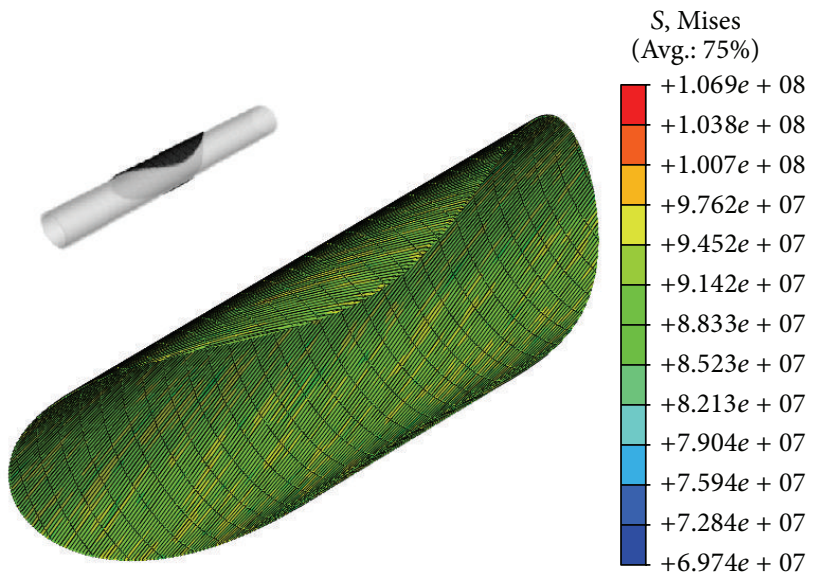

FIgURE 11: Mises-stress contour for nonfriction tension armor 1 under tension.

and friction effect between steel strips of the tension armor. However, as it shows in Figure 10, for discrete structure like tension armor, stress concentration caused by theses interactions between strips could not be ignored.

Extrusion and slip appear between strips when tension is applied. From Figure 10, the distribution of contact pressure can be observed easily. The effect of friction makes stress of the strips smaller than that from nonfriction model. This can be easily verified by comparison of Mises stress from model without friction effect (shown in Figure 11) and that from

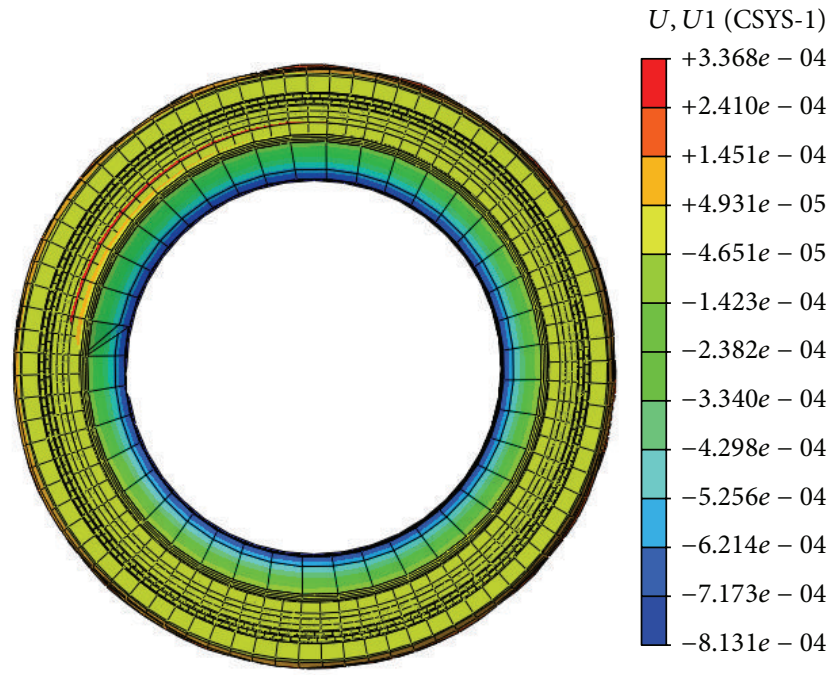

FIGURE 12: Radial deformation contour for the riser under internal pressure.

model with friction effect (shown in Figure 9). Calculated stress result decreases by $7.8 \%$ when friction is considered.

4.2. Load Case 2: Internal Pressure. In this load case, a 6.4 MPa internal pressure was applied on the carcass layer of the riser. The radial deformation of the riser shows in Figure 12 (deformation scale factor 25). The results for the maximum Mises stress of each layer are listed in Table 4. It illustrates that the internal pressure transits from internal structure to external structure layer by layer through contact.

Under internal pressure, the pressure protection armor layers (interlocking pressure protection armor layer and preparatory pressure protection armor layer) are the main structures to resist load. The maximum hoop-stress in the two pressure protection armor layers is $98.57 \mathrm{MPa}$ as shown in Figure 13.

The numerical results are compared with those from Lame's formula in elastic mechanics shown as the following equation [13]:

$$
\sigma_{\varphi}=-\frac{R^{2} / \rho^{2}+1}{R^{2} / r^{2}-1} q
$$

where $R$ is the external radius of the cylinder, $\rho$ is the radius of an arbitrary point of the cylinder, and $r$ is the inner radius of the cylinder.

The analytical result is $93.34 \mathrm{MPa}$, smaller than the numerical result $98.57 \mathrm{MPa}$ by $5.3 \%$. Contact pressure distribution of channel steel strips is shown in Figure 14. The results 
TABle 5: Maximum Mises stress of each layer.

\begin{tabular}{lcccccc}
\hline & $\begin{array}{c}\text { Carcass } \\
\text { layer }\end{array}$ & $\begin{array}{c}\text { Inner pressure } \\
\text { protection } \\
\text { armor }\end{array}$ & $\begin{array}{c}\text { Interlocking } \\
\text { pressure } \\
\text { protection } \\
\text { armor }\end{array}$ & $\begin{array}{c}\text { Preparatory } \\
\text { pressure } \\
\text { protection } \\
\text { armor }\end{array}$ & $\begin{array}{c}\text { Tension } \\
\text { armor 1 }\end{array}$ & $\begin{array}{c}\text { Tension } \\
\text { armor 2 }\end{array}$ \\
\hline Mises stress $(\mathrm{MPa})$ & 4.917 & 0.09979 & 71.70 & 75.37 & 59.62 & 50.89 \\
sheath & 0.9359 \\
\hline
\end{tabular}
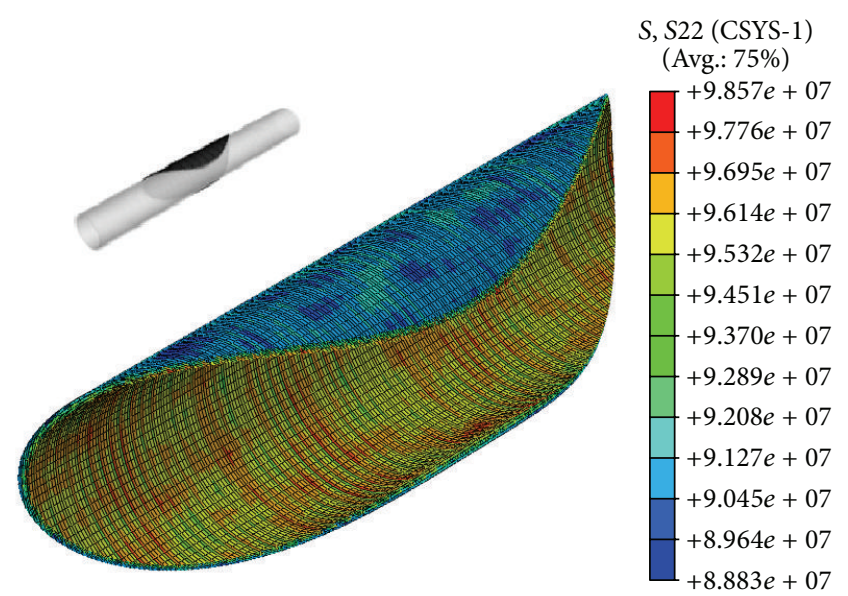

FIGURE 13: Hoop-stress contour for the pressure protection armor layers under internal pressure.

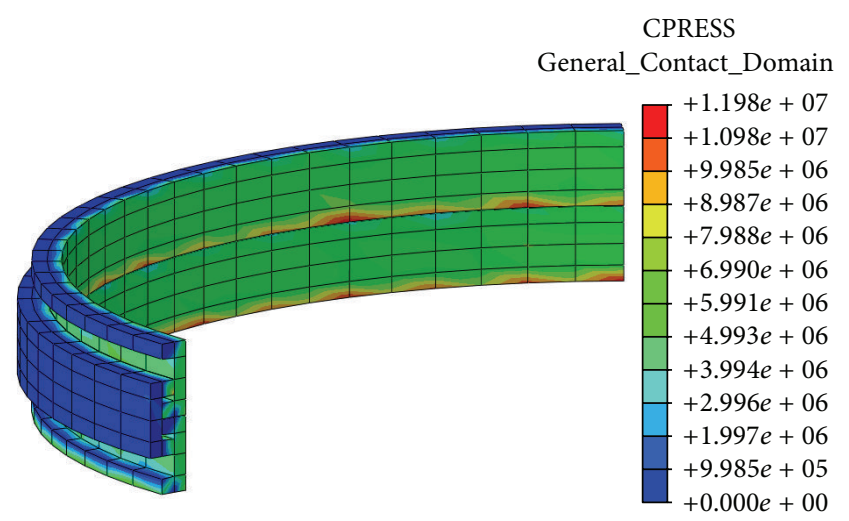

FIGURE 14: Contact pressure contour for channel steel strips under internal pressure.

from the simulation agree well with the analytical results from $\mathrm{Xu}$ [13].

4.3. Load Case 3: External Pressure. The external pressure is $2 \mathrm{MPa}$, acting on the outer sheath layer. The radial deformation of the riser under external pressure is shown in Figure 15 (deformation scale factor 25). The maximum Mises-stress results of each layer are listed in Table 5. It illustrates that the external pressure transits from external structure to internal structure layer by layer through contact.

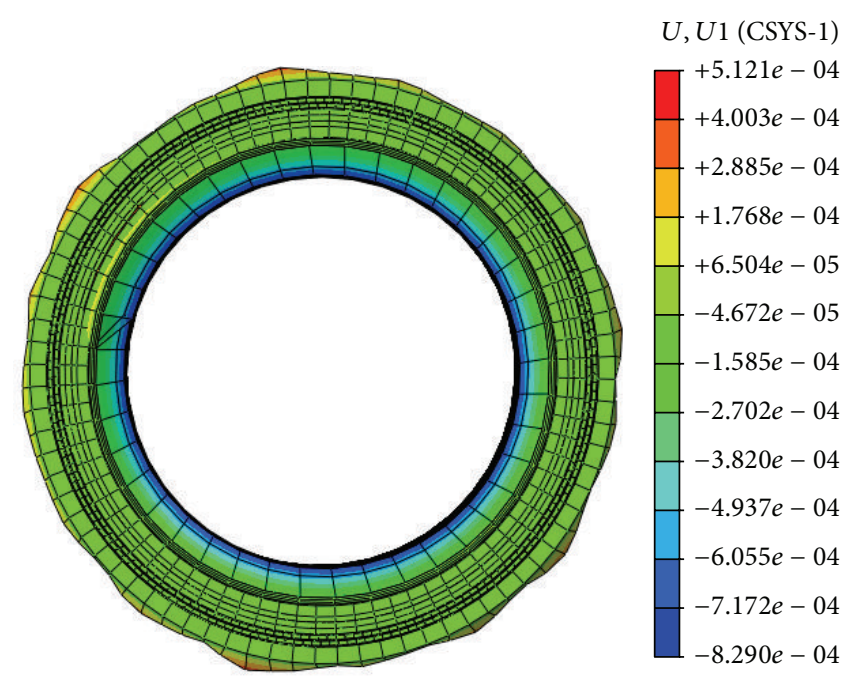

FIGURE 15: Radial deformation contour for the riser under external pressure.

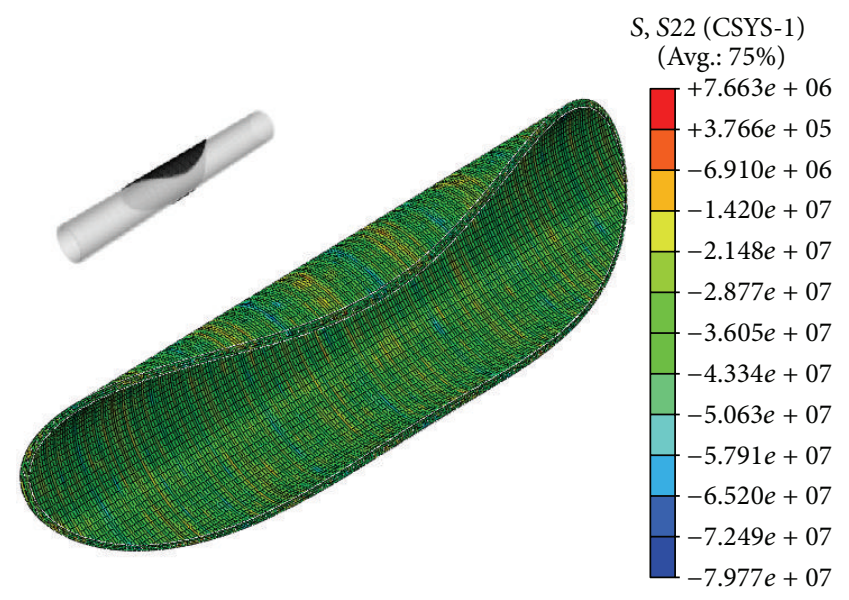

FIGURE 16: Hoop-stress contour for the pressure protection armor layers under external pressure.

The external pressure is mostly resisted by the pressure protection armor layers (interlocking pressure protection armor layer and preparatory pressure protection armor layer). The maximum hoop-stress in the two pressure protection armor layers is $7.663 \mathrm{MPa}$ as shown in Figure 16. Contact pressure distribution of channel steel strips is shown in Figure 17. 


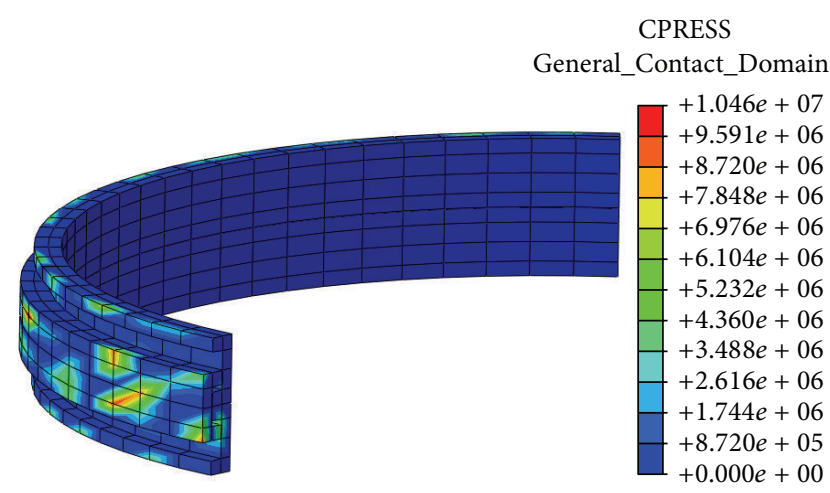

FIGURE 17: Contact pressure contour for channel steel strips under external pressure.

\section{Conclusions}

(1) A detailed finite element model for a 10-layer unbonded flexible riser has been created for the analysis of its mechanical behavior. It takes into account geometric nonlinearity, contact interaction, and friction.

(2) From the calculation in ABAQUS, detailed stress and deformation results of each layer of the riser under three load cases are obtained. The calculation results show a satisfactory agreement with those from analytical method. It verifies the numerical method's validation.

(3) It suggests that the finite element model can be used to predict mechanical behavior of the riser in other different load cases. The numerical model enables cost-effective parametric investigations, which can in turn lead to improved riser design.

\section{Conflict of Interests}

The authors declare that there is no conflict of interests regarding the publication of this paper.

\section{Acknowledgments}

This research was supported by National Science Foundation of China (51279206) and Beijing Natural Science Foundation (3144029).

\section{References}

[1] R. H. Knapp, "Derivation of a new stiffness matrix for helically armored cables considering tension and torsion," International Journal for Numerical Methods in Engineering, vol. 14, no. 4, pp. 515-529, 1979.

[2] J. Lanteigne, "Theoretical estimation of the response of helically armored cables to tension, torsion, and bending," Transactions ASME-Journal of Applied Mechanics, vol. 52, no. 2, pp. 423432, 1985.

[3] J. J. Feret and C. L. Bournazel, "Calculation of stresses and slip in structural layers of unbonded flexible pipes," ASME Journal of Offshore Mechanics and Arctic Engineering, vol. 109, no. 3, pp. 263-269, 1987.

[4] I. Kraincanic and E. Kebadze, "Slip initiation and progression in helical armouring layers of unbonded flexible pipes and its effect on pipe bending behaviour," Journal of Strain Analysis for Engineering Design, vol. 36, no. 3, pp. 265-275, 2001.

[5] E. Kebadze, Theoretical modeling of unbonded flexible pipe crosssections [Ph.D. thesis], South Bank University, London, UK, 2000.

[6] J. J. Feret and C. L. Bournazel, "Calculation of stresses and slip in structural layers of unbonded flexible pipes," Journal of Offshore Mechanics and Arctic Engineering, vol. 109, no. 3, pp. 263-269, 1987.

[7] A. M. Harte and J. F. McNamara, "Modeling procedures for the stress analysis of flexible pipe cross sections," Journal of Offshore Mechanics and Arctic Engineering, vol. 115, no. 1, pp. 46-51, 1993.

[8] P. Claydon, G. Cook, P. A. Brown, and R. Chandwani, "A theoretical approach to prediction of service life of unbonded flexible pipes under dynamic loading conditions," Marine Structures, vol. 5, no. 5, pp. 399-429, 1992.

[9] G. Alfano, A. Bahtui, and H. Bahai, "Numerical derivation of constitutive models for unbonded flexible risers," International Journal of Mechanical Sciences, vol. 51, no. 4, pp. 295-304, 2009.

[10] A. Bahtui, H. Bahai, and G. Alfano, "A finite element analysis for unbonded flexible risers under torsion," Journal of Offshore Mechanics and Arctic Engineering, vol. 130, no. 4, Article ID 041301, 2008.

[11] ABAQUS Theory Manual, ABAQUS, Version 6.10 Documentation, 2010.

[12] ISO, Recommended Practice for Flexible Pipe. ISO 13628-11:2007, International Organization for Standardization, London, UK, 2007.

[13] Z. L. Xu, Elastic Mechanics, Version 2, 1982. 


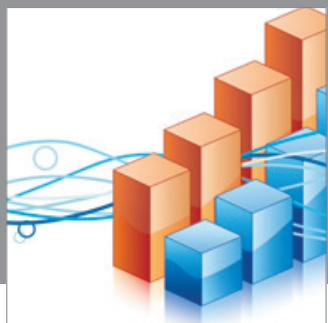

Advances in

Operations Research

mansans

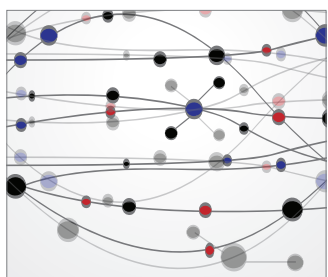

The Scientific World Journal
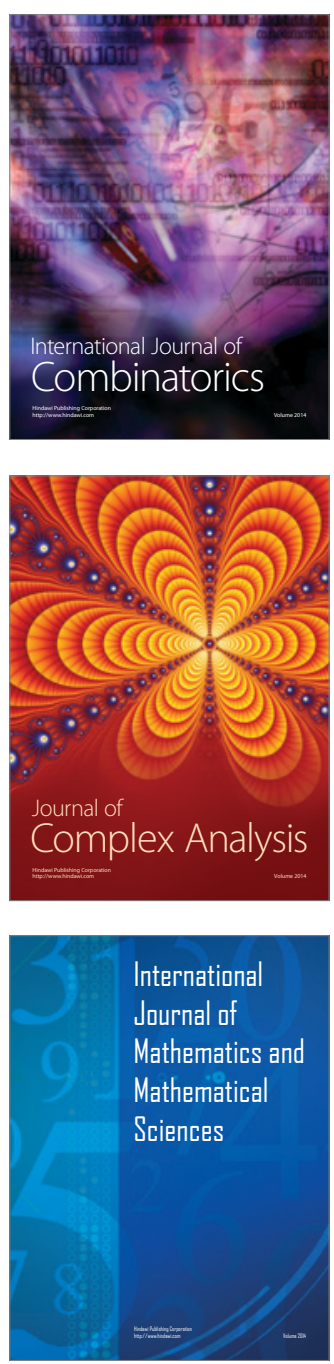
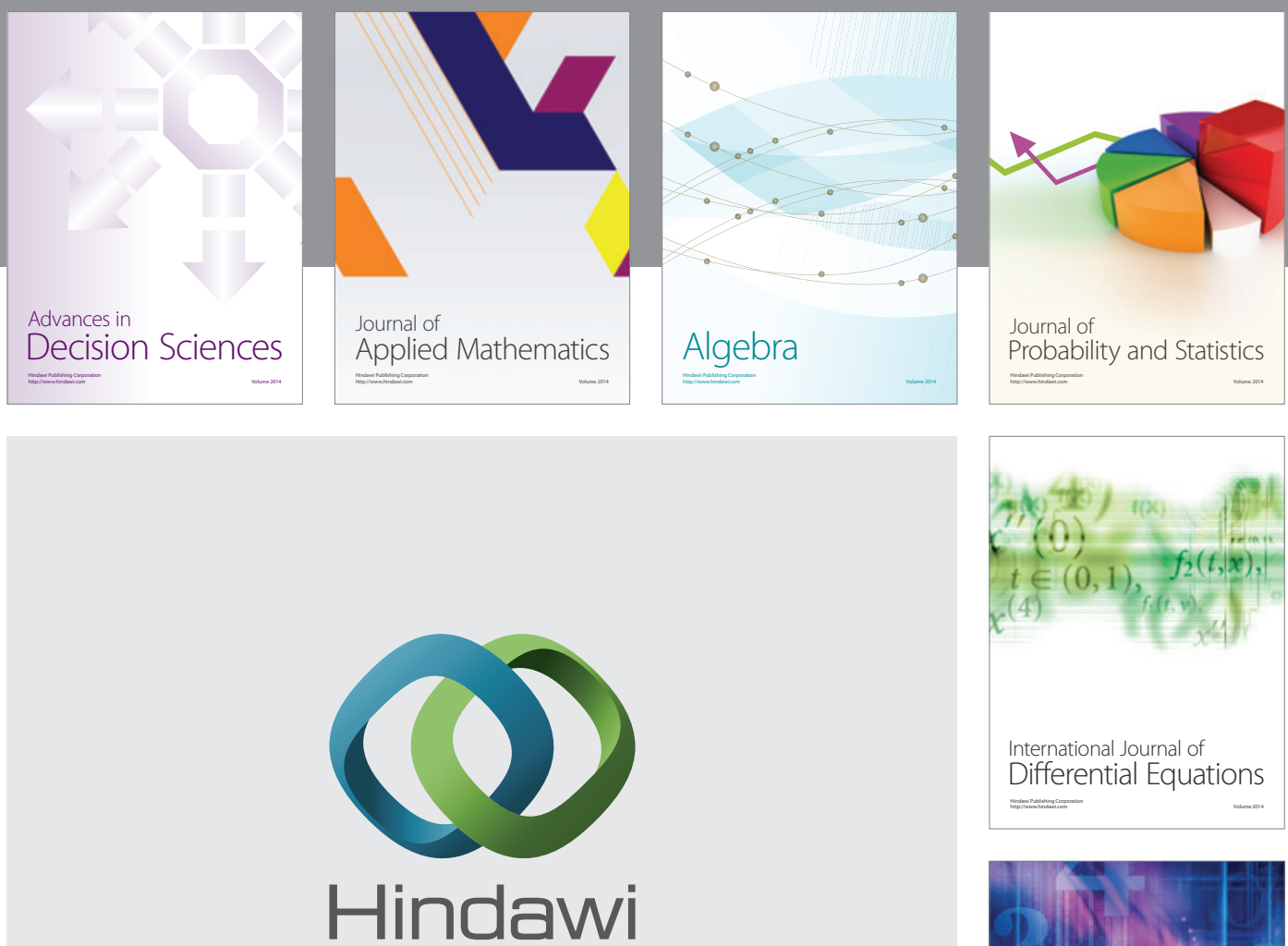

Submit your manuscripts at http://www.hindawi.com
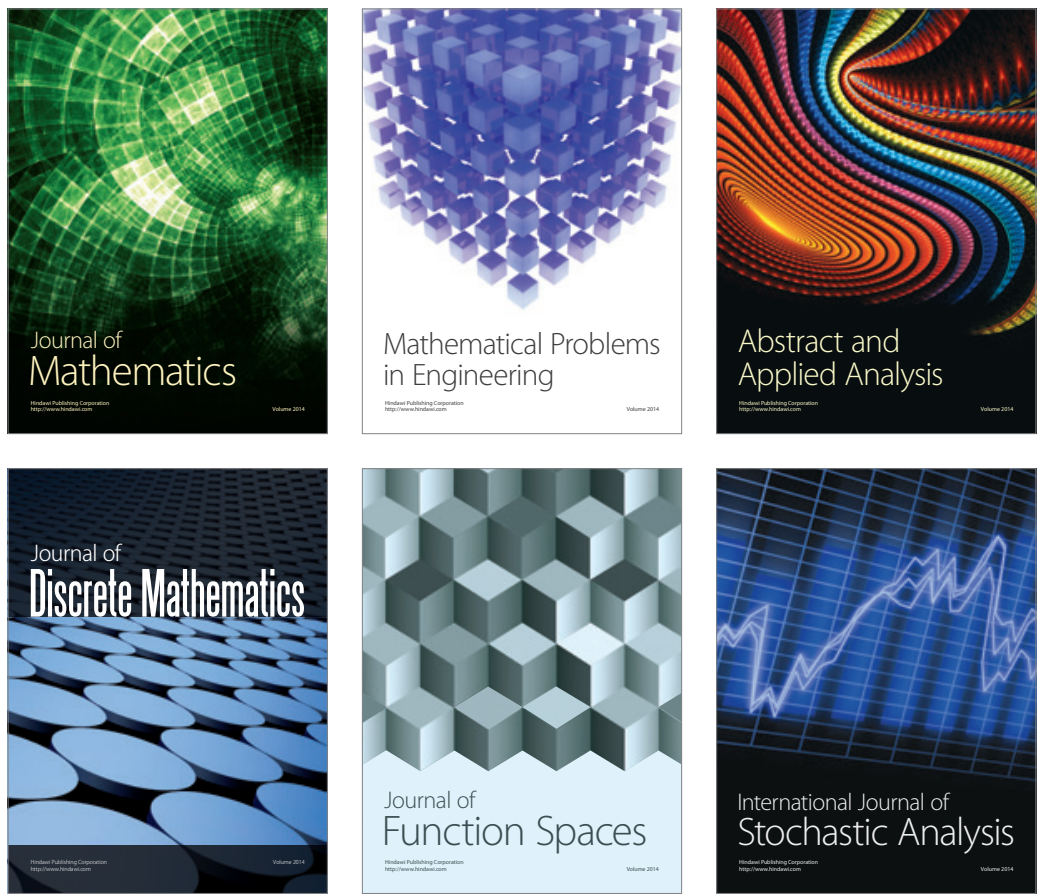

Journal of

Function Spaces

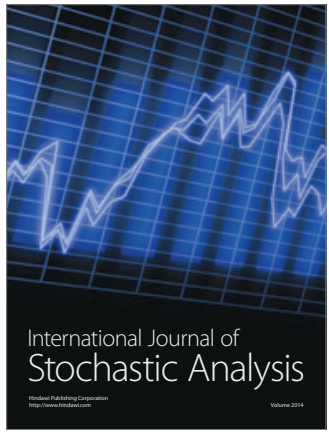

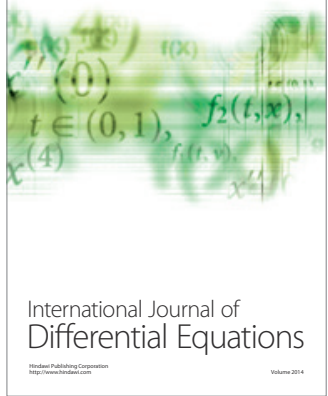
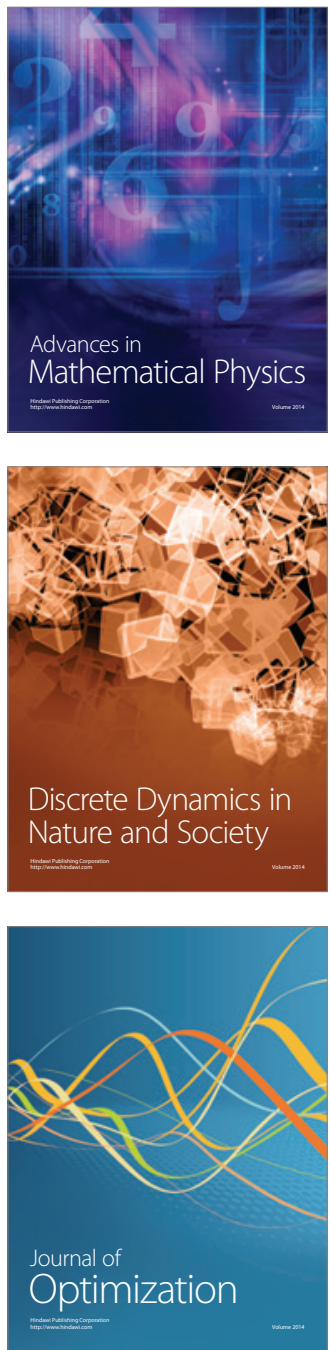